\title{
REVIEW OF THE NEOTROPICAL GENUS FLINTIELLA (TRICHOPTERA: HYDROPTILIDAE: STACTOBIINI)
}

\author{
Steven C. Harris, ${ }^{1}$ Oliver S. Flint, Jr. ${ }^{2}$ and Ralph W. Holzenthal ${ }^{3}$ \\ ${ }^{1}$ Department of Biology, Clarion University, Clarion, Pennsylvannia 16214, USA \\ (E-mail: harris@clarion.edu); \\ ${ }^{2}$ Department of Entomology, National Museum of Natural History, Smithsonian \\ Institution, Washington, DC 20560, USA (E-mail: flint.oliver@nmnh.si.edu); and \\ ${ }^{3}$ Department of Entomology, University of Minnesota, \\ St. Paul, Minnesota, 55108, USA (E-mail: holze001@umn.edu)
}

\begin{abstract}
The Neotropical genus Flintiella is reviewed and eight new species are described and illustrated: $F$. alajuela from Costa Rica, F. boraceia from Brazil, $F$. panamensis from Panama, F. tamaulipasa from Mexico, F. yanamona from Peru, F. heredia from Costa Rica, Ecuador, and Peru, F. astilla from Brazil, Costa Rica, Ecuador, Paraguay, Peru, and Venezuela, and $F$. pizotensis from Columbia, Costa Rica, Ecuador, Mexico, Panama, and Peru. New illustrations are provided for $F$. andreae Angrisano. Keys are provided to separate the males and the associated females of the nine known species in the genus.
\end{abstract}

Key words: Trichoptera, Hydroptilidae, microcaddisflies, Flintiella, new species, Neotropics, key

This paper on the genus Flintiella is another addition to a continuing series initially intended to describe the microcaddisfly fauna of Costa Rica. As in preceding papers, we have had to consider the systematics of the group under consideration, and in doing so we have had to expand our coverage beyond Costa Rica, encompassing the entire Neotropical region. The genus Flintiella was erected by Angrisano (1995) for a series of microcaddisflies collected in Uruguay and Argentina. With this paper we expand the diversity of the genus with the addition of eight new species, and the range of distribution, with the new species occurring throughout Central and South America.

Flintiella is assigned to the tribe Stactobiini, which as currently defined contains 12 genera, most of which occur in the Old World. In the New World, there are five genera presently known: Stactobiella in North America; and Bredinia, Flintiella, Orinotrichia, and Tizatetrichia in the Neotropics. In the Neotropics, the genera Orinocotrichia and Tizatetrichia were covered by Harris et al. (2002a), and the genus Bredinia by Harris et al. (2002b). Adults of Flintiella are minute (1-3 mm in length) and brown in alcohol. The genus is most closely related to Orinocotrichia based on the absence of ocelli, the triangular posterior warts on the head, and the elongate apodemes from the anterolateral margin of abdominal segment IX. The females of the two genera are also similar, based on the common "keyhole" structure of the vaginal sclerite of the bursa copulatrix. Flintiella is separated from Orinocotrichia on the basis of the complex structure of the subgenital plate, the presence of a diagonal row of short setae on the forewing, and the anterior position of the vaginal sclerite, which is posterior in Orinocotrichia. The larvae of Flintiella, described by 
Angrisano (1995) are typical stactobine-type, laterally compressed with silk cases; larvae of Orinocotrichia are unknown.

Types of species described in this paper, as indicated by acronym in the text, are deposited in the collections of the National Museum of Natural History, Smithsonian Institution (NMNH), the University of Minnesota Insect Collection (UMSP), the California Academy of Science (CAS), the Carnegie Museum of Natural History (CMNH), the Museum of Zoology, Universidade de Sao Paulo, Brazil (MZUSP), Instituto Nacional de Biodiversidad Heredia, Costa Rica (INBIO), and Universidad Nacional Autonoma de Mexico (UNAM). Terminology follows that of Marshall (1979). Length is measured from the tip of the head to the end of the wings and is given as a range with a series of specimens.

\section{Flintiella Angrisano}

(Fig. 1)

Flintiella Angrisano, 1995: 502.

Type species. Flintiella andreae Angrisano 1995, original designation.

Diagnosis. The genus Flintiella was established by Angrisano (1995) for a species, $F$. andreae, collected in Uruguay and Argentina. Adults of the genus are minute (1.5-2.5 $\mathrm{mm}$ in length) and brown in alcohol. The head lacks ocelli and possesses simple antennae having 16-18 segments (Fig. 1A). Mesoscutellum divided by a transverse suture. Wings thin with reduced venation, forewing with diagonal line of short setae (Fig. 1C). Legs with a tibial spur formula of 0, 2, 3 (Fig. 1B). Males with abdominal segment VII with or without short apicomesal process from the venter. Segment VIII annular. Segment IX with elongate anterolateral apodemes and reduced ventrally to narrow bridge, venter often with mesal U-shaped notch on posterior margin. Inferior appendages elongate. Subgenital plate usually complex and divided into several processes. Phallus tubular, often divided at apex. Females similar to males in overall coloration and features of the head and thorax. Elongate apodemes from posterior and lateral margins of abdominal segment VIII. Segment IX with lateral apodemes. Bursa copulatrix with keyhole-like opening near anterior margin, mesally narrowing subapically. Larva laterally compressed with elongate, rectanguloid head, anterior ecdysial suture lines indistinct, elongate setae anteriorly. Thoracic sclerites square in shape and divided mesally. Prothoracic legs short and robust, tibia with pair of heavy spines at apex; meso- and metathoracic legs thin and elongate. Abdomen widened without dorsal sclerotization, excepting segment IX. Anal prolegs small with single apical hook. Case constructed of silk and laterally compressed.

Flintiella alajuela, new species

(Fig. 2)

Diagnosis. An atypical member of the genus with no close relatives. The fused inferior appendages, with posterodorsal cluster of spines, and simple shelf-like subgenital plate are all unique to $F$. alajuela. The species has been found at a single locality on the Rio Pizote in Costa Rica.

Description. Male. Length $2.0 \mathrm{~mm}$. Antennae broken but with more than $11 \mathrm{seg}$ - 


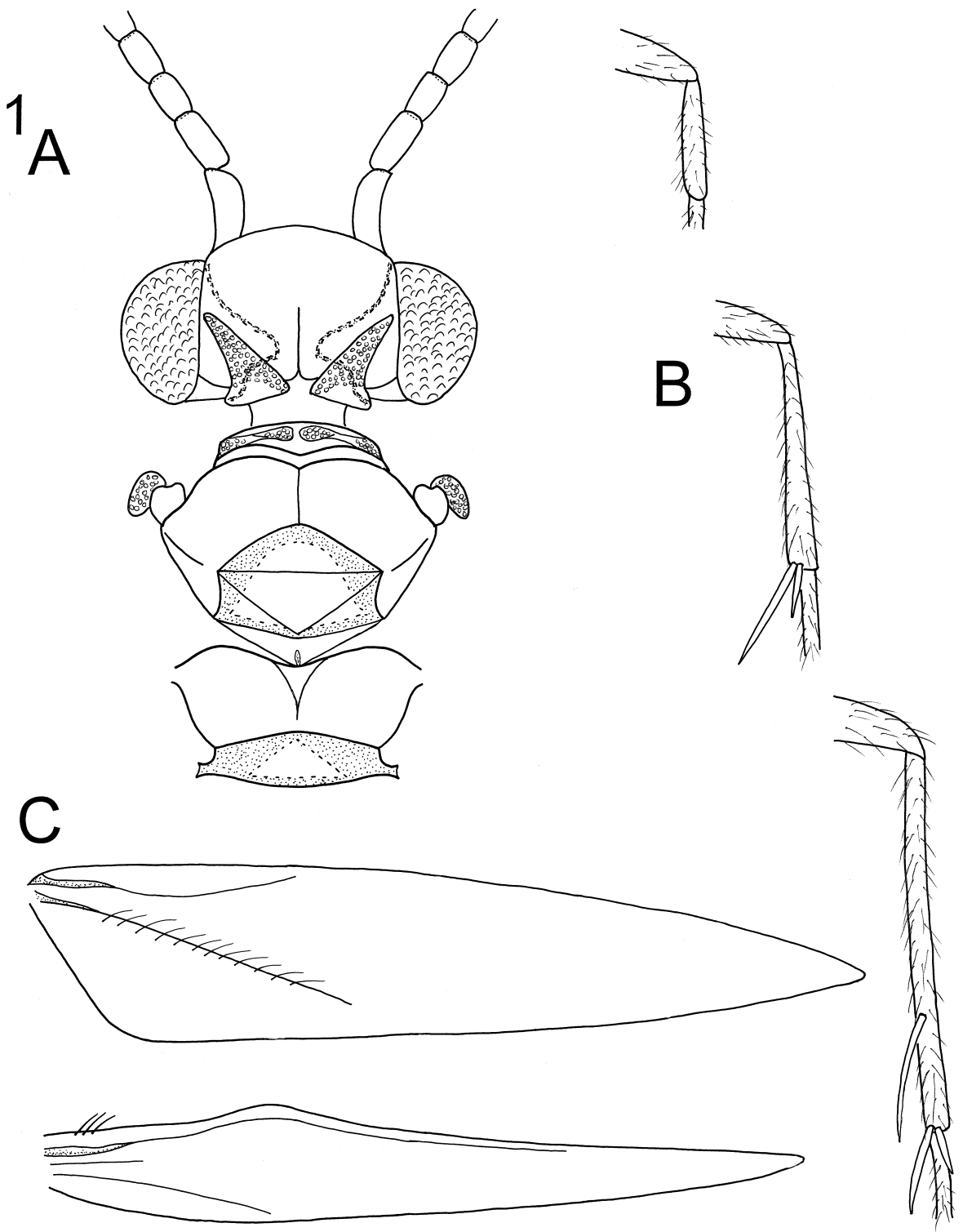

Fig. 1. Flintiella pizotensis new species, adult. A. Head and thorax, dorsal. B. Fore, mid, and hindleg. C. Fore and hindwing. 

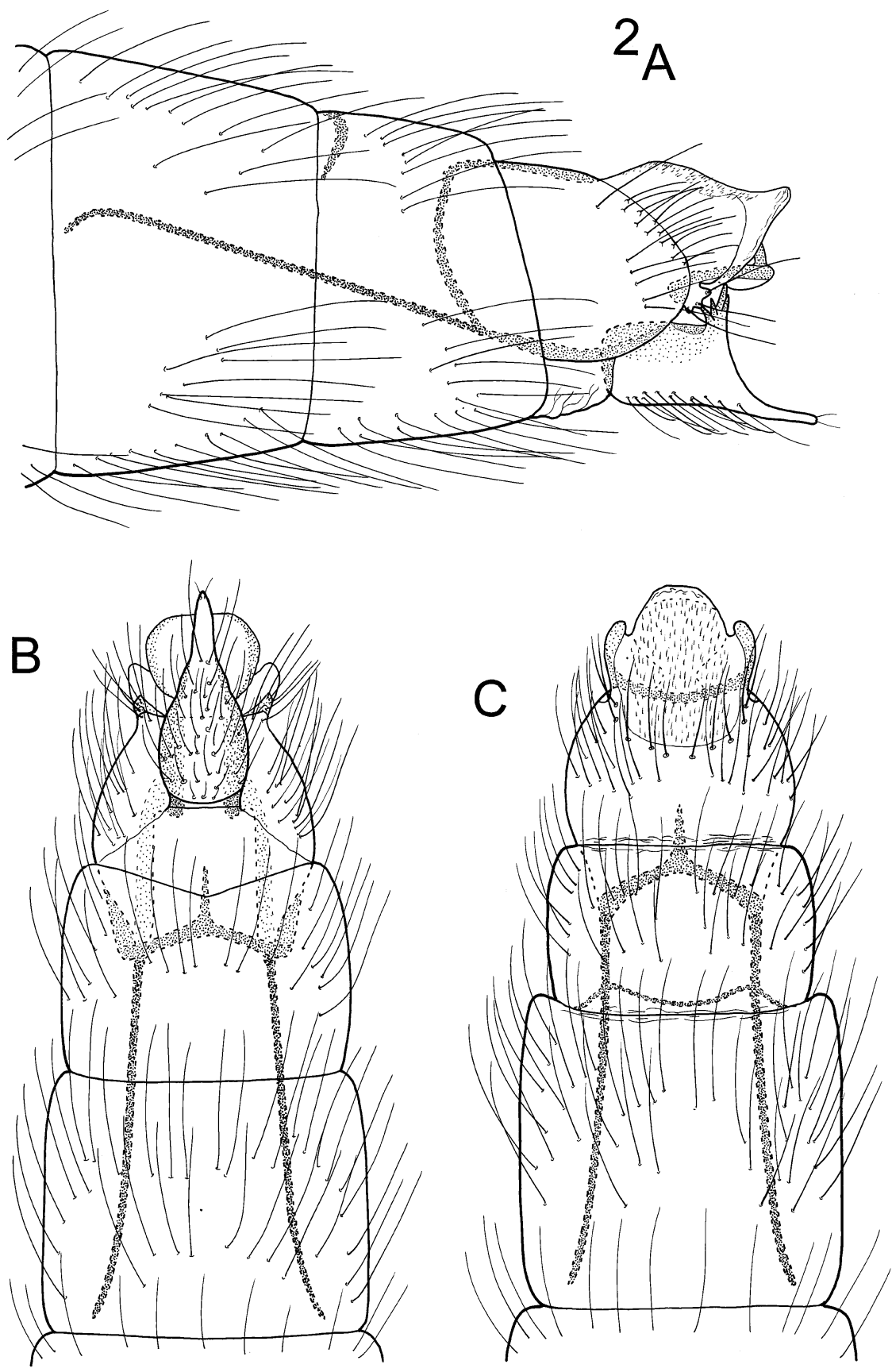

Fig. 2. Flintiella alajuela new species, male genitalia. A. Lateral. B. Ventral. C. Dorsal. 
ments. Brown in alcohol. Genitalia as in Fig. 2. Abdominal segment VII annular with no posterior process from the venter. Segment VIII annular; slightly emarginate on posterior margin in ventral view. Segment IX lobate, reduced ventrally; in dorsal view rounded laterally and partially fused with $\mathrm{X}$, anterolateral margins developed as thin, elongate rods which extend through segment VII. Segment X triangular in lateral view; in dorsal view round. Inferior appendages rectangular in lateral view, spinose posterodorsally, posteroventrally narrowing to thin shelf, in ventral view fused, narrowly triangluar. Subgenital plate a narrow shelf in lateral view. Phallus missing.

Female. Unknown.

Types. Holotype, ${ }^{\top}$ : COSTA RICA, Alajuela, Rio Pizote, ca. $5 \mathrm{~km}$ N Dos Rios, $10.948^{\circ} \mathrm{N}, 85.291^{\circ} \mathrm{W}$, el. $40 \mathrm{~m}, 9-\mathrm{III}-1986$, Holzenthal \& Fasth (NMNH)

Etymology. Named for the Costa Rican province of Alajuela.

Flintiella boraceia, new species

(Fig. 3)

Diagnosis. Flintiella boraceia is another highly modified member of the genus. Although the extremely long apodemes from the anterior of segment IX are shared with several species, only this species and $F$. astilla, n. sp. have spinal processes from the dorsum of segment IX. These processes are elongate in F. boraceia and short and hook-like in $F$. astilla. The structure of the phallic apex which bears a pair of small spines and the shape of the inferior appendages are unique to $F$. boraceia and atypical of Flintiella. Flintiella boraceia is only known from the type locality in Brazil.

Description. Male. Length $1.9 \mathrm{~mm}$. Antenna with 16 segments. Brown in alcohol. Genitalia as in Fig. 3. Abdominal segment VII with short apicomesal process from venter. Segment VIII annular. Segment IX reduced ventrally to narrow bridge, elongate, thin processes posterodorsally; in dorsal view, elongate rods anterolaterally extending into segment V, posteriorly thin, sclerotized process laterally. Segment $\mathrm{X}$ lobate in lateral view, in dorsal view broadly triangular. Inferior appendages narrowing posteroventrally to acute point; in ventral view elongate laterally, slightly converging on mesal margin. Subgenital plate in lateral view bifid, ventral process wide and curving downward; in ventral view, wide and rounded basally, narrowing distally and converging, apices acute and curved inward. Phallus tubular, widening to flattened apex, small spines laterally; ejaculatory duct protruding.

Female. Unknown.

Types. Holotype, ơ: BRAZIL, Sao Paulo, Estacion Biologica Boraceia, 17-III-1983, C. Froehlich (MZUSP).

Etymology. Named for the biological station in Brazil where the species was collected.

Flintiella astilla, new species

(Figs. 4, 11)

Diagnosis. Although sharing the common feature of spines on segment IX with $F$. boraceia, $F$. astilla is more closely related to the following new species, $F$. pizoten- 


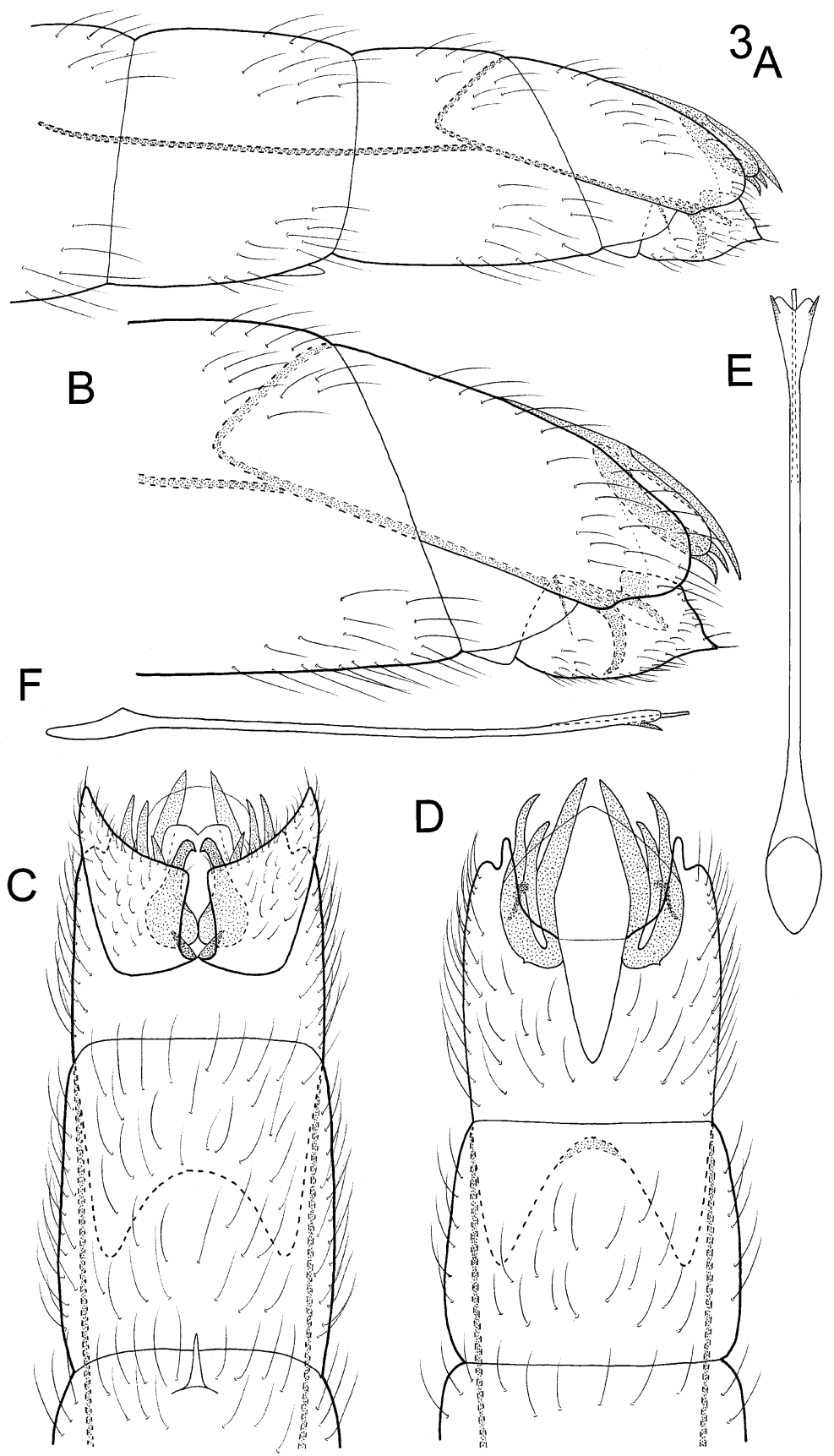

Fig. 3. Flintiella boraceia new species, male genitalia. A. Lateral, segments VI-X. B. Lateral, segments VIII-X. C. Ventral. D. Dorsal. E. Phallus, dorsal. F. Phallus, lateral. 


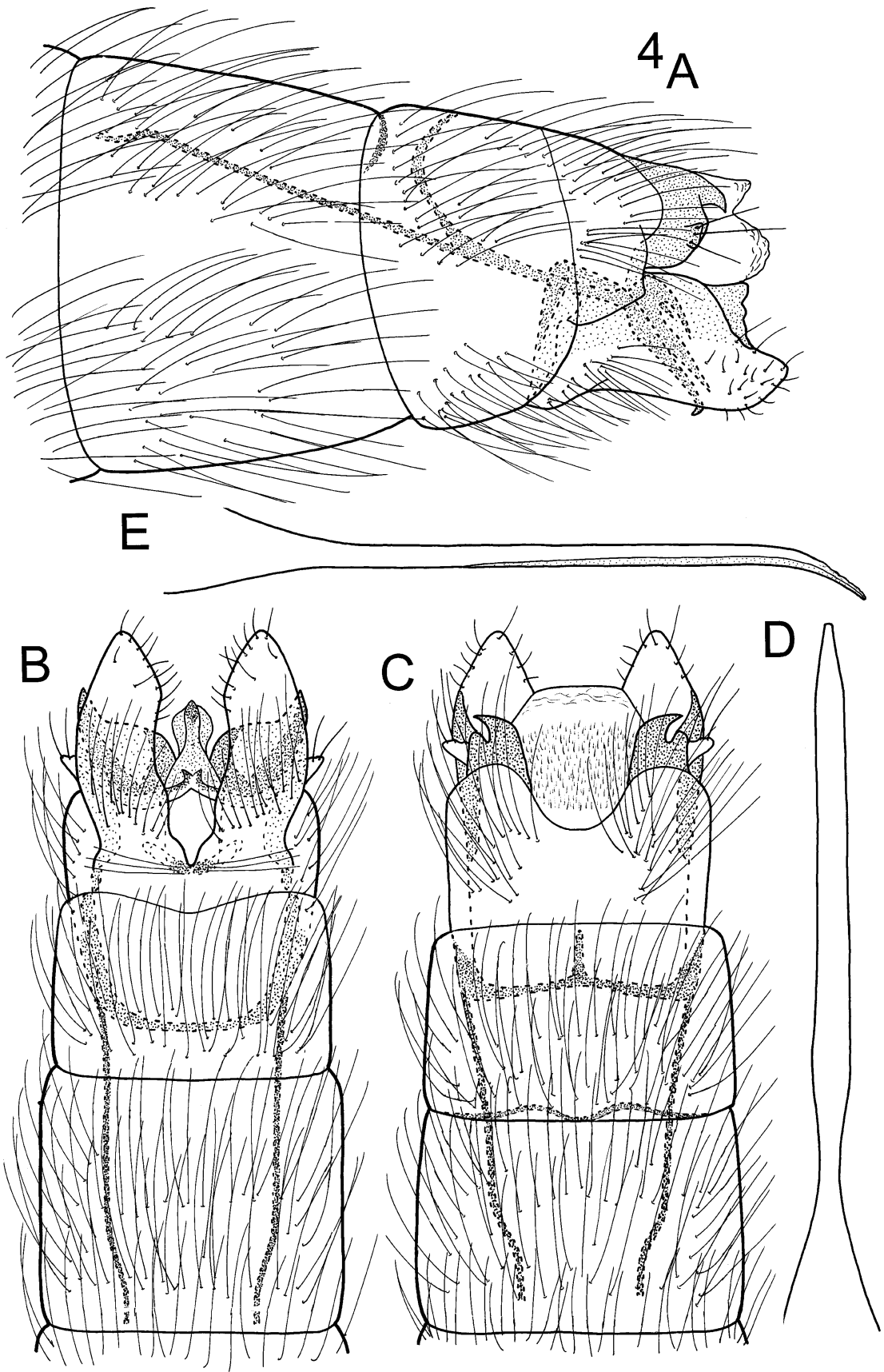

Fig. 4. Flintiella astilla new species, male genitalia. A. Lateral. B. Ventral. C. Dorsal. D. Phallus, dorsal. E. Phallus, lateral. 
sis. Both $F$. astilla and $F$. pizotensis have a simple tubular phallus with apex entire, but in $F$. astilla this apex narrows, while in $F$. pizotensis it widens. The shape of the inferior appendages and the complex structure of the subgenital plate is also similar in the two species. Flintiella astilla is most easily recognized by the large posterolateral hooks on segment IX. The species is fairly widespread in the Neotropics, with records from Brazil, Costa Rica, Ecuador, Paraguay, Peru and Venezuela.

Description. Male. Length $1.8-2.2 \mathrm{~mm}$. Antenna with 18 segments. Brown in alcohol. Genitalia as Fig. 4. Abdominal segment VII annular with no posterior process from the venter. Segment VIII annular. Segment IX reduced ventrally to narrow bridge, dorsally with large, sclerotized hooks posterolaterally, posterior margin emarginate, anterolateral margins developed as thin elongate rods which extend through segment VII. Segment X lobate in lateral view; in dorsal view quadrate. Inferior appendages shoe-shaped, narrowing posteroventrally; in ventral view elongate, narrowing to rounded apices, rounded on lateral margins, diverging on mesal margin. Subgenital plate in lateral view with 3 or 4 elongate posterior processes; in ventral view a wide plate, mesally triangular with lateral lobes distally. Phallus tubular, nearly parallel-sided, narrowing to blunt apex.

Female. Length $1.8-2.5 \mathrm{~mm}$. Antenna with 17 segments. Coloration and overall features of the head and thorax as in male. Genitalia as in Fig. 11. Abdominal segment VII annular. Segment VIII rectangular, ring of setae on posterior margin, pair of elongate, mesal apodemes extending into segment VI, second pair of elongate apodemes originating at anterolateral margins and extending into segment VII. Segment IX short and rectanguloid with pair of lateral apodemes connecting with mesal apodemes of VIII. Segment X short and conical, bearing pair of lateral papillae. Bursa copulatrix oval with posterior narrowing to nipple-like projection, membranous subapically; internally with keyhole-like anterior opening, pair of rods forming outer margin of keyhole structure and running posteriad.

Types. Holotype o: VENEZUELA, Amazonas, Rio Cataniapo, $10 \mathrm{~km} \mathrm{~S}$ Puerto Ayacucho, 9-III-1984, O. Flint (NMNH). Paratypes: VENEZUELA, Amazonas: same locality and data as holotype, 12 t, 5 \& (NMNH); San Carlos de Rio Negro, $1^{\circ} 56^{\prime} \mathrm{N}, 67^{\circ} 03^{\prime} \mathrm{W}, 13-17-\mathrm{XII}-1984$, R. Brown, 1 ơ (NMNH). BRAZIL, Bahia: Rio Sao Francisco Sobradinho, 16-II-1989, E. Rosa, 22 o , 36 (MZUSP, NMNH); same locality, but Juazeiro, 3-II-1989, 13 o, 66 (MZUSP, NMNH); same locality but, 16-II-1989, 15 o (NMNH). Mato Grosso: bridge on Rio Arica on Cuiaba to Rondonoplis road near km 34 marker, 22-IV-1981, D. Wojcik, 3 o (NMNH). Parana: Rio Parana, Guaira, el. 215 m, 10-III-1969, W. \& J. Peters, 1 o (NMNH). Sao Paulo: Piracicaba, 22-I-1965, C. \& W. Triplehorn, blacklight, 2 ot, 2 ( (UMSP); same locality but, 10-II-1965, 1 के (NMNH); same but, 12-III-1965, 7 §, 4 ㅇ (UMSP); same but, 30-XII-1964, 1 ô, 10 ㅇ (NMNH); same but, 25-I-1965, 1 ô, 3 q (NMNH). COSTA RICA, Guanacaste: Rio Mena, $4.2 \mathrm{~km} \mathrm{~W}$ Santa Cecilia, $11.059^{\circ} \mathrm{N}, 85.448^{\circ} \mathrm{W}$, el. $260 \mathrm{~m}, 11-\mathrm{III}-1986$, Holzenthal \& Fasth, 7 q (UMSP). ECUADOR, Napo: Puerto Montufar, 29-IV-1976, J. Cohen, 3 ô, 12 $q$ (NMNH). PARAGUAY, Concepcion: Concepcion, 13-14-II-1990, J. Kochalka, blacklight, 1 क (NMNH); same locality but, 9-13-II-1990, 1 ô, 1 क (NMNH). PERU, Loreto: Sucusari River at Explornapo Camp, 13-I-1993, L. Davenport, 1 đo (CMNH); same locality but, 12-III-1991; 2 ô, Yanamono River just below Explorama Lodge, 10-I- 
1993, L. Davenport, 1 o (CMNH); tributary to Yanamono River, at Explorama Lodge, 11-III-1991, L. Davenport, 1 ô (CMNH); small stream adjacent to grounds of Explorama Lodge, 20-I-1995, 1 ơ (UMSP); small creek at outlet of Lake Shimigay, ca. $2 \mathrm{~km}$ upstream Napo River from mouth Sucusari River, 15-I-1993, L. Davenport, 11 ô (UMSP); edge of quiet backwater near Sucusari River adjoining Explornapo Camp, 16-I-1993, L. Davenport, 3 o (UMSP).

Etymology. Spanish, "splinter," referring to the spines of the ninth segment.

Flintiella pizotensis, new species

(Figs. 5, 12)

Diagnosis. This new species is fairly widespread occurring from Mexico, through Central America, into northern South America. It is most similar to F. astilla, from which it differs in the absence of dorsolateral hooks from segment IX, the more triangular inferior appendages, the structure of the phallic apex, and the presence of a small posteroventral process on segment VII.

Description. Male. Length 1.6-2.2 mm. Antenna with 18 segments. Brown in alcohol. Genitalia as in Fig. 5. Abdominal segment VII annular; short posterior process from venter. Segment VIII annular. Segment IX reduced ventrally to narrow bridge; dorsally with posterior margin emarginate, anterolateral margins developed as thin, elongate rods which extend through segment VII. Segment X lobate in lateral and dorsal views. Inferior appendages boot-shaped, narrowing posteroventrally; elongate and narrowly triangular in ventral view. Subgenital plate complex, in lateral view with dorsal and ventral processes; in ventral view tapering distally with apex bearing several spinal processes. Phallus tubular, nearly parallel-sided, widening apically; ejaculatory duct protruding at apex.

Female. Length 1.8-2.3 mm. Antenna with 17 segments. Coloration and general appearance of head and thorax as in male. Genitalia as in Fig. 12. Abdominal segment VII annular. Segment VIII rectangular, ring of setae on posterior margin, pair of elongate mesal apodemes extending into segment VI, second pair of elongate apodemes originating at anterolateral margins and extending into segment VII. Segment IX short and square with pair of lateral apodemes connecting with mesal apodemes of VIII. Segment X short, rounded distally, bearing pair of lateral papillae. Bursa copulatrix thin, narrowing posteriorly to nipple-like projection, lateral margins widening apically and basally, sclerotized near base, keyhole opening anteriorly.

Types. Holotype, ${ }^{\star}$ : COSTA RICA, Limon, Rio Telire and small tributaries SE Suretka, $9.554^{\circ} \mathrm{N}, 82.892^{\circ} \mathrm{W}$, el. 48 m. 1-II-1986, Holzenthal, Morse, Fasth (NMNH). Paratypes: COSTA RICA, Limon, same locality and data as holotype, 4 o (UMSP); Hacienda Tapezco, 21-III-1979, J. Donahue, 1 ơ, 2 (CAS); same locality but, 25 km (air) W. Tortuguero, 21-III-1978, Donahue et al., 1 đ (CAS); same but, 29 km (air) W Tortuguero, el. $40 \mathrm{~m}, 10^{\circ} 30^{\prime} \mathrm{N}, 83^{\circ} 47^{\prime} \mathrm{W}, 14-\mathrm{III}-1978$, Donahue et al., 1 , 4 (CAS); same but, 21-III-1978, J. Donahue, 1 के (CAS); La Suerta, 25-27-VIII1979, J. Donahue, 1 क (NMNH); same locality but, 14-17-VIII-1979, 2 ô, 3 ㅇ (CAS); Corcori, Cariari, el. 1,000 m, X-1992, F. Munoz, 2 ô (INBIO). Alajuela: Rio Pizote, ca. $5 \mathrm{~km}$ (air) S. Brasilia, $10.972^{\circ} \mathrm{N}, 85.345^{\circ} \mathrm{W}$, el. $390 \mathrm{~m}, 12-\mathrm{III}-1986$, Holzenthal \& Fasth, 400 oิ (CMNH, UMSP); Rio Pizote, ca. $5 \mathrm{~km}$ N Dos Rios, $10.948^{\circ} \mathrm{N}, 85.291^{\circ} \mathrm{W}$, el. $470 \mathrm{~m}, 9-\mathrm{III}-1986$, Holzenthal \& Fasth, 408 ơ (CMNH, 


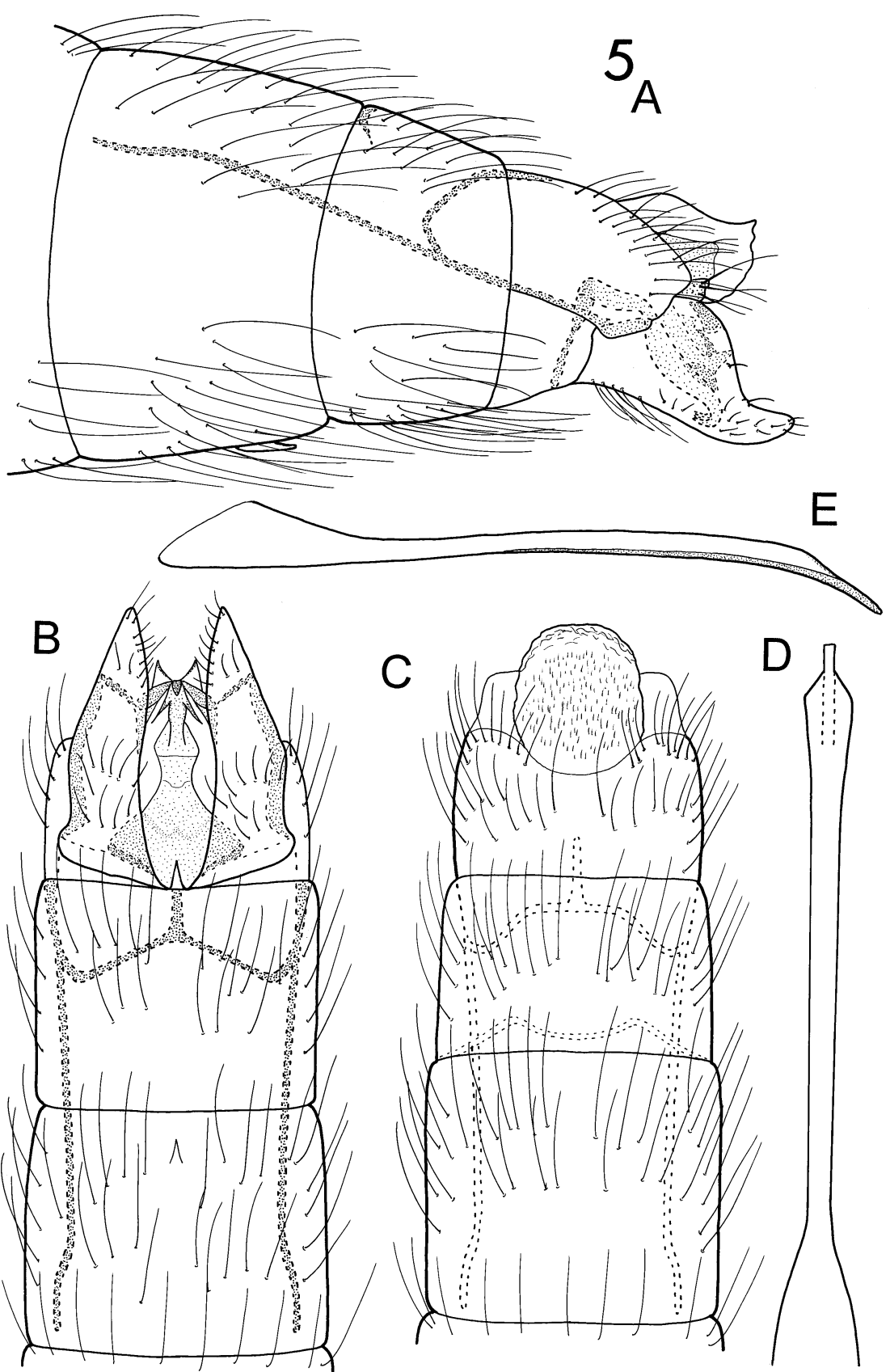

Fig. 5. Flintiella pizotensis new species, male genitalia. A. Lateral. B. Ventral. C. Dorsal. D. Phallus, dorsal. E. Phallus, lateral. 
UMSP), Guanacaste: Rio Mena, $4.2 \mathrm{~km} \mathrm{~W}$ Santa Cecilia, $11.059^{\circ} \mathrm{N}, 85.448^{\circ} \mathrm{W}$, el. 260 m, 11-III-1986, 78 oิ, 7 (UMSP); Quebrada Garcia, 10.6 km ENE Quebrada Grande, $10.862^{\circ} \mathrm{N}, 85.428^{\circ} \mathrm{W}$, el. $470 \mathrm{~m}, 8-\mathrm{III}-1986$, Holzenthal \& Fasth, 1 o (UMSP). Heredia: Estacion Biologica La Selva, Quebrada Sura, $10.437^{\circ} \mathrm{N}$, $84.010^{\circ} \mathrm{W}$, el. $50 \mathrm{~m}, 20-21-\mathrm{VI}-1986$, Holzenthal, Heyn, Armitage, 90 oे (NMNH, UMSP); Rio Sarapiqui, $7 \mathrm{~km} \mathrm{~W}$ Puerto Viejo, $10.452^{\circ} \mathrm{N}, 84.067^{\circ} \mathrm{W}$, el. $50 \mathrm{~m}, 11-\mathrm{II}-$ 1986, Morse \& Fasth, 52 ( $\left(\right.$ UMSP); Rio Bijagual on road to Magsasay, $10.408^{\circ} \mathrm{N}$, $84.076^{\circ} \mathrm{W}$, el. $140 \mathrm{~m}, 12-\mathrm{II}-1986$, Holzenthal, Morse, Fasth, 11 oิ, 31 o (UMSP); La Selva, 28 April 1989, Agriculture Canada, 52 o (NMNH); La Selva Field Station, near Puerto Viejo, $10^{\circ} 26^{\prime} \mathrm{N}, 83^{\circ} 59^{\prime} \mathrm{W}, 1-3-\mathrm{IV}-1987, \mathrm{~J}$. Hill, 24 ô, 16 ๆ (NMNH); same locality but, 21-28-III-1988, 31 of, 11 o (NMNH). COLOMBIA, Valle del Cauca: Rio Raposa, VIII-1965 V. Lee, 1 o (NMNH); same locality but, III-1965, 1 ô, 1 ㅇ (NMNH); same but, IV-1965, 1 के, 1 ㅇ (NMNH); same but, 5-III-1961, 1 के (NMNH), same but, I-1964 3 ô, 2 क (NMNH). ECUADOR, Esmeraldas: La Union, 3-II-1979, blacklight, J. Anderson, 10 oิ (NMNH). Cotopaxi: Quevado (36 km NE), 21-VII-1976, blacklight, el. 340 m, J. Cohen, 17 tै (NMNH). Los Rios: Queveda (5 km S), 14-I-1978, Spangler \& Anderson, 20 to, 3 ㅇ (NMNH), same locality but, 28-29-VII-1976, J. Cohen, 2 o (NMNH). Napo: Limoncocha, 14-VI1977, Spangler \& Givens, 2 o, 1 ㅇ, (NMNH). Pichincha: Santo Domingo de los Colorados (29 km W), 6-V-1975, P. Spangler, 1 ô (NMNH); Santo Domingo (47 $\mathrm{km} \mathrm{S}$ ), Rio Palenque, Biological Station, 29-VII-1976, J. Cohen, 39 o (NMNH). MEXICO, Tabasco: Rio Puyacatengo, E. Teapa, 28-29-VII-1966, Flint \& Ortiz, 5 o (NMNH). NICARAGUA, Zelaya: Rio Waspuk, Rapido Waula Kumbas, el. 75 m, $14^{\circ} 21^{\prime} \mathrm{N}, 8^{\circ} 36^{\prime} \mathrm{W}, \mathrm{IX}-1996$, Maes \& Hernandez, 4 ơ, 15 ㅇ (NMNH). PANAMA, Darien: Rio Tuira at Rio Pucuro, 16-17-II-1985, J. Louton, 1 o (NMNH). Panama: Barro Colorado Island, Snyder-Molino trail, marker 3, light trap I, 30-XI-6-XII-1988, H. Wolda, 1 ơ (NMNH). PERU, Loreto: Sucusari River, just upstream Explornapo Camp 16-I-1991, L. Davenport, 1 ô (CMNH).

Etymology. Named for the Rio Pizote in Costa Rica where the species was commonly collected.

\section{Flintiella andreae Angrisano}

(Figs. 6, 13)

Flintiella andreae Angrisano, 1995: 503.

Diagnosis. Flintella andreae, the type species for the genus, is similar to $F$. heredia, n. sp. in many respects. Both species have the apex of the phallus incised, but shallowly, and both have similarly shaped inferior appendages. Flintiella andreae is separated from $F$. heredia on the basis of the posteromesal lobes from the inferior appendages, the short subgenital plate, and the twisted apex of the phallus. To date, $F$. andreae is only known from Uruguay and Argentina (Flint et al. 1999).

Description. Male. Length $1.7 \mathrm{~mm}$. Antenna with 18 segments. Brown in alcohol. Genitalia as in Fig. 6. Abdominal segments VII and VIII annular. Segment IX reduced ventrally; dorsally with rounded lateral margins, tapering posteriorly and fused with $\mathrm{X}$, anteriorly with lateral margins developed as thin, elongate rods which extend through segment VII; ventrally with mesal U-shaped notch posteriorly. Segment X shelf-like and membranous in lateral view; in dorsal view, narrow basally, widening 


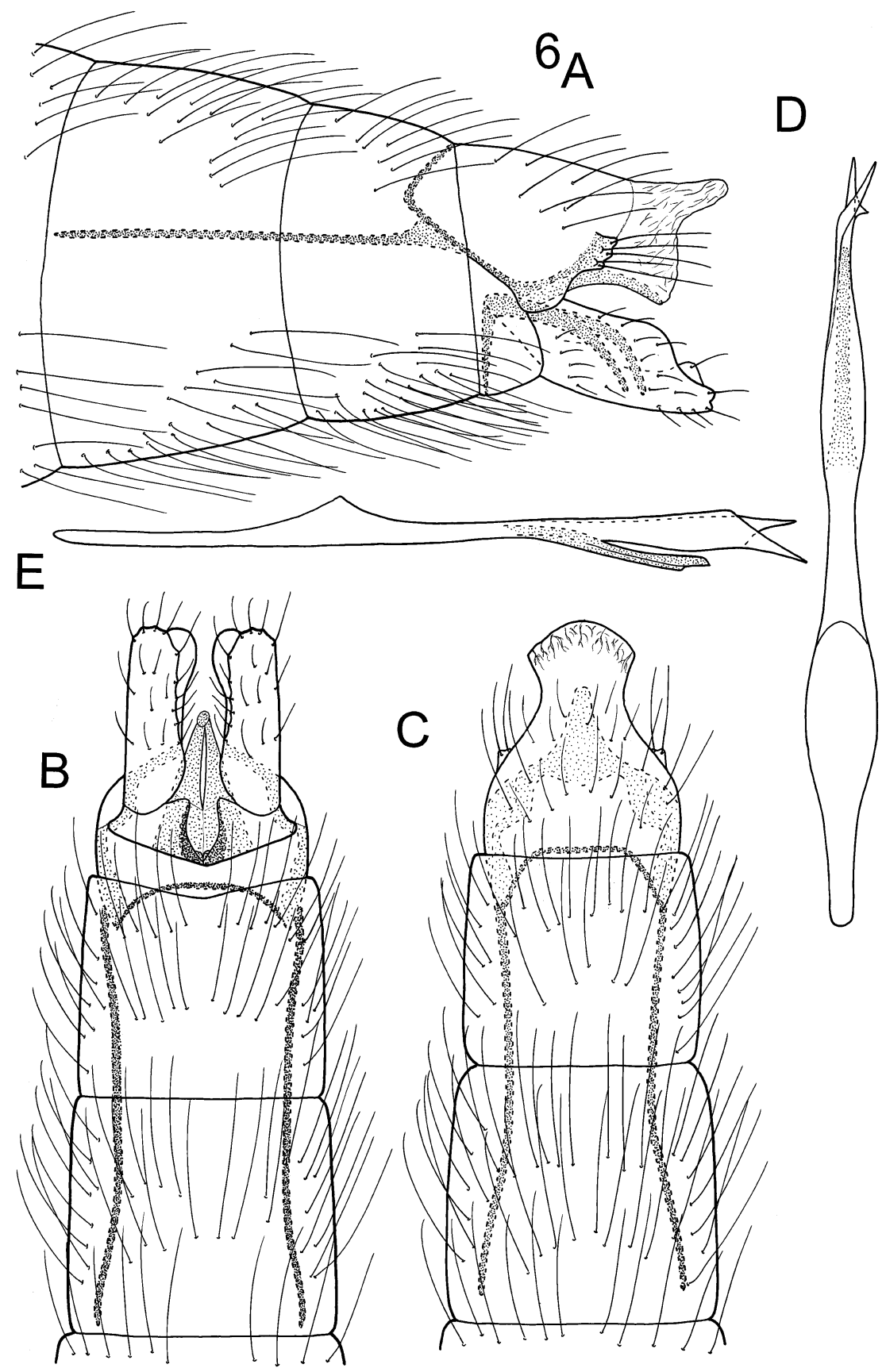

Fig. 6. Flintiella andreae Angrisano, male genitalia. A. Lateral. B. Ventral. C. Dorsal. D. Phallus, dorsal. E. Phallus, lateral. 
distally to rounded apex. Inferior appendages rectangular, narrow incision posteroventrally; in ventral view rectangular with elongate lobe posterodorsally. Subgenital plate in lateral view thin, divided distally into two narrow processes; in ventral view triangular, about half length of inferior appendages, lateral processes nearly contiguous. Phallus tubular, apex divided into two asymmetrical lateral processes.

Female. Length $1.7 \mathrm{~mm}$. Antenna with 17 segments. Coloration and overall appearance of head and thorax as in male. Genitalia as in Fig. 13. Abdominal segment VII annular. Segment VIII with rectangular ring of setae on posterior margin, pair of elongate, mesal apodemes extending through segment VII, second pair of elongate apodemes originating at anterolateral margins and extending through segment VII. Segment IX short and tapering posteriorly to emarginate margin, pair of lateral apodemes connecting anteriorly with mesal apodemes of VIII. Segment X short and conical, bearing pair of apical papillae. Bursa copulatrix oval, lateral margins of keyhole opening narrowing mesad, then widening posteriorly.

Material examined. URUGUAY, Artigas: Arroyo de La Invernada, 19-21-II-1954, Carbonell \& de Zolesii, 1 o, 1 \& paratypes (NMNH); same locality but, 21-II-1954, C. Carbonell, 4 ô (NMNH). Durazno: Arroyo del Cordobes, Pasa de la Cruz, 5-II1953, San Martin \& de Zolesii, 1 ô (NMNH).

Flintiella heredia, new species

(Figs. 7, 14)

Diagnosis. Based on phallic structure, and general appearance of the inferior appendages and subgenital plate, $F$. heredia appears to be most closely related to the preceding species. This new species is distinguished from $F$. andreae by the presence of a posteroventral process on segment VII, the structure of the phallus apex, and the lack of posteromesal lobes on the inferior appendages. Flintiella heredia is fairly widespread, with records from Costa Rica, Ecuador, and Peru.

Description. Male. Length 1.6-2.0 mm. Antenna with 18 segments. Brown in alcohol. Genitalia as in Fig. 7. Abdominal segment VII annular, venter with short posterior process. Segment VIII annular. Segment IX reduced ventrally to narrow bridge; dorsally with rounded lateral margins, tapering posteriorly and fused with X, anteriorly with lateral margins developed as thin elongate rods which extend through segment VII; ventrally with deep mesal cleft. Segment X lobate in lateral view; in dorsal view narrow basally, widening distally to truncate apex. Inferior appendages rectangular, tapering posteroventrally; in ventral view elongate and rectangular, rounded at apex. Subgenital plate in lateral view thin and elongate, divided into two processes; in ventral view triangular, nearly as long as inferior appendages, two processes nearly contiguous. Phallus tubular, shallow excision at apex.

Female. Length 1.6-2.4 mm. Antenna with 17 segments. Coloration and overall features of head and thorax as in male. Genitalia as in Fig. 14. Abdominal segment VII annular and tapering posteriorly. Segment VIII rectangular, ring of setae on posterior margin, pair of elongate mesal apodemes extending through segment VII, second pair of elongate apodemes originating at anterolateral margins and extending into segment VII. Segment IX short and square, membranous posteriorly with pair of lateral apodemes connecting with mesal apodemes of VIII. Segment X short and conical, bearing pair of apical papillae. Bursa copulatrix widest at midlength, nar- 


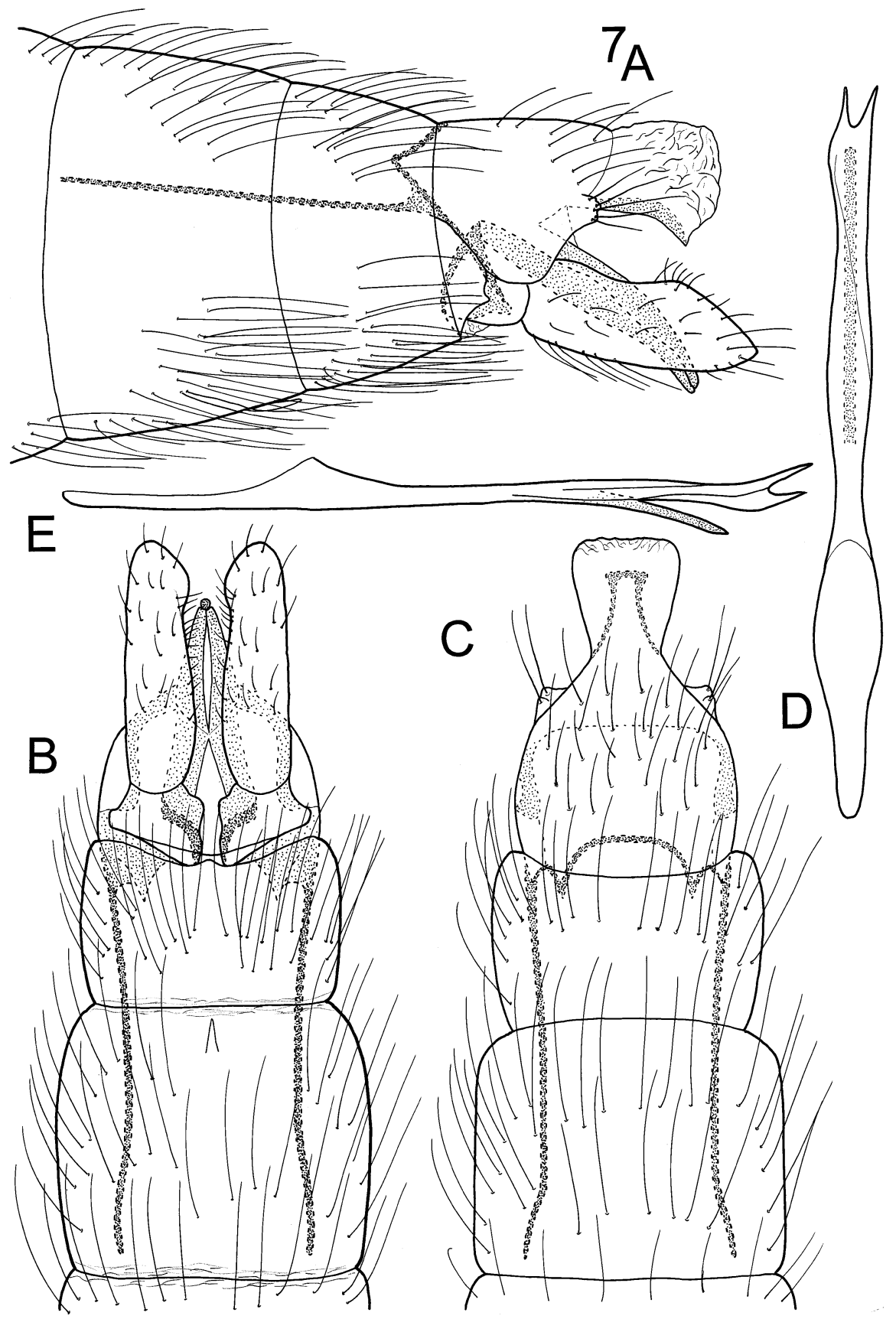

Fig. 7. Flintiella heredia new species, male genitalia. A. Lateral. B. Ventral. C. Dorsal. D. Phallus, dorsal. E. Phallus, lateral. 
rowing posteriorly and anteriorly. Anterior keyhole structure narrowing posteriorly, surrounded by circular structure which narrows posteriorly.

Types. Holotype, $\hat{0}$ : COSTA RICA, Heredia, Rio Bijagual on road to Magsasay, $10.408^{\circ} \mathrm{N}, 84.076^{\circ} \mathrm{W}$, el. $140 \mathrm{~m}, 12-\mathrm{II}-1986$, Holzenthal, Morse, Fasth (NMNH). Paratypes: COSTA RICA, Heredia: same locality and data as holotype, $27 \hat{0}, 15$ + (INBIO, NMNH, UMSP). Puntarenas: Quebrada Pita, ca. $3 \mathrm{~km}$ (air) W. Golfito, $8.642^{\circ} \mathrm{N}, 83.193^{\circ} \mathrm{W}$, el. $15 \mathrm{~m}, 15-\mathrm{II}-1986$, Holzenthal, Morse, Fasth, 1 o (UMSP). ECUADOR, Pastaza: Puyo, 8 May 1977, Spangler \& Givens, blacklight, 1 đ (NMNH). PERU, Loreto: stream at outlet of Lake Shimigay, ca $2 \mathrm{~km}$ upstream Napo River from mouth of Sucusari River, 15-I-1993, L. Davenport, 1 o (CMNH). Etymology. Named for the Costa Rican province of Heredia.

Flintiella panamensis, new species (Fig. 8)

Diagnosis. Flintiella panamensis is most similar to the following new species, $F$. tamaulipasa from Mexico. Both have the phallus apex deeply divided, and similarly shaped inferior appendages in lateral aspect. From $F$. tamaulipasa, and all other Flintiella, $F$. panamensis is separated by the bilobed tenth segment. Flintiella panamensis is also distinguished from $F$. tamaulipasa, but linked with $F$. yanamona, $\mathrm{n}$. sp., which also has a deeply divided phallic apex, by the presence of a posteroventral process from segment VII. Flintiella panamensis is only known from Barro Colorado Island in Panama.

Description. Male. Length $1.7 \mathrm{~mm}$. Antenna with 18 segments. Brown in alcohol. Genitalia as in Fig. 8. Abdominal segments VII annular and bearing a short posteroventral process. Segment VIII annular. Segment IX reduced ventrally; square in dorsal view, anteriorly with lateral margins developed as thin, elongate rods which extend through segment VII; ventrally with deep mesal notch. Segment X thinly triangular in lateral view; dorsally divided into pair of elongate lobes. Inferior appendages triangular, abruptly narrowing posterodorsally; in ventral view triangular, rounded apically. Subgenital plate in lateral view thin and shelf-like, divided into three distal processes; in ventral view triangular, about 3/4 length of inferior appendages. Phallus tubular, deeply divided distally, ejaculatory duct protruding about $1 / 2$ length of incision.

Female. Unknown.

Types. Holotype, ô: PANAMA, Panama, Barro Colorado Island, Snyder-Molino trail, marker 3, 15-21-VI-1988, light trap I, H. Wolda (NMNH).

Etymology. Named for the country of Panama.

\section{Flintiella tamaulipasa, new species}

(Figs. 9, 15)

Diagnosis. Flintiella tamaulipasa is separated from the similar $F$. panamensis and F. yanamona, n. sp. by the absence of a posteroventral process from segment VII and by the shape of the inferior appendages. The inferior appendages lack the posteromesal lobes seen in $F$. panamensis, but they are less acute posteriorly than those of $F$. yanamona. Flintiella tamaulipasa is only know from a few localities in Mexico. 

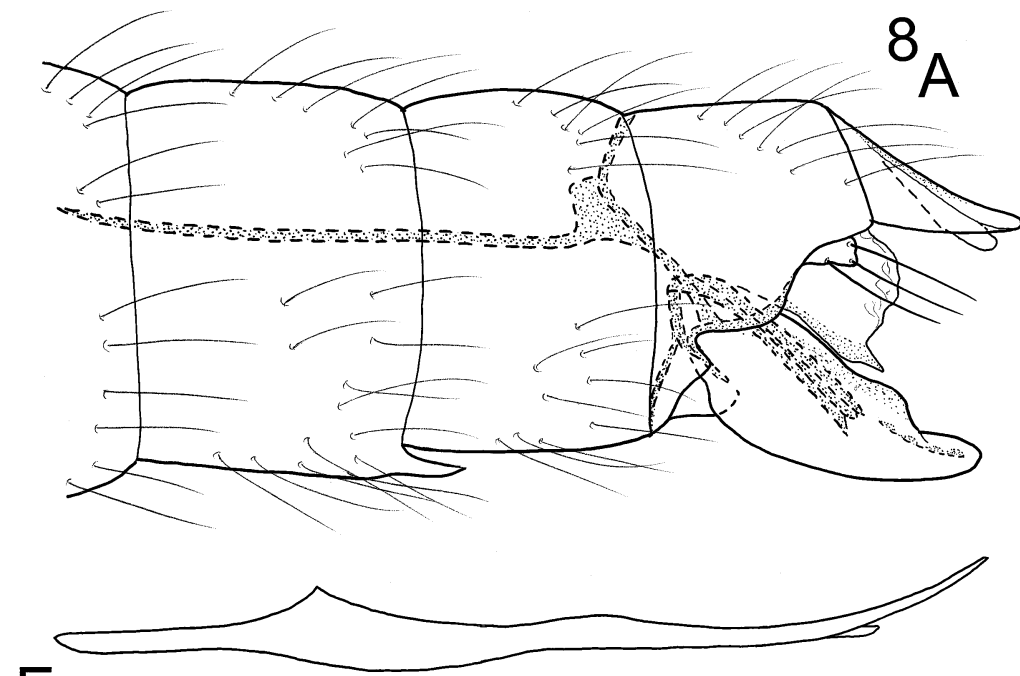

$E$
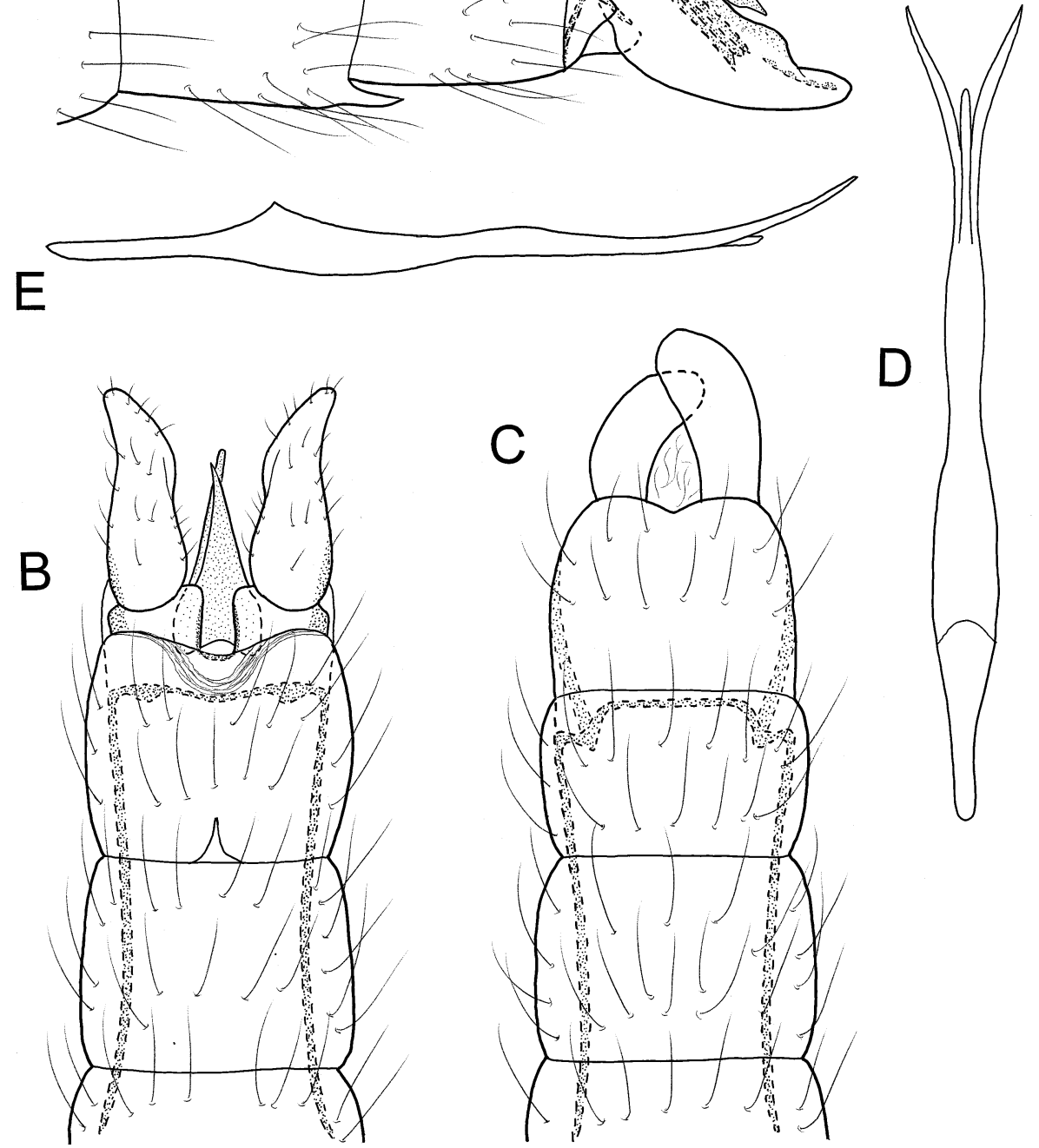

Fig. 8. Flintiella panamensis new species, male genitalia. A. Lateral. B. Ventral. C. Dorsal. D. Phallus, dorsal. E. Phallus, lateral. 


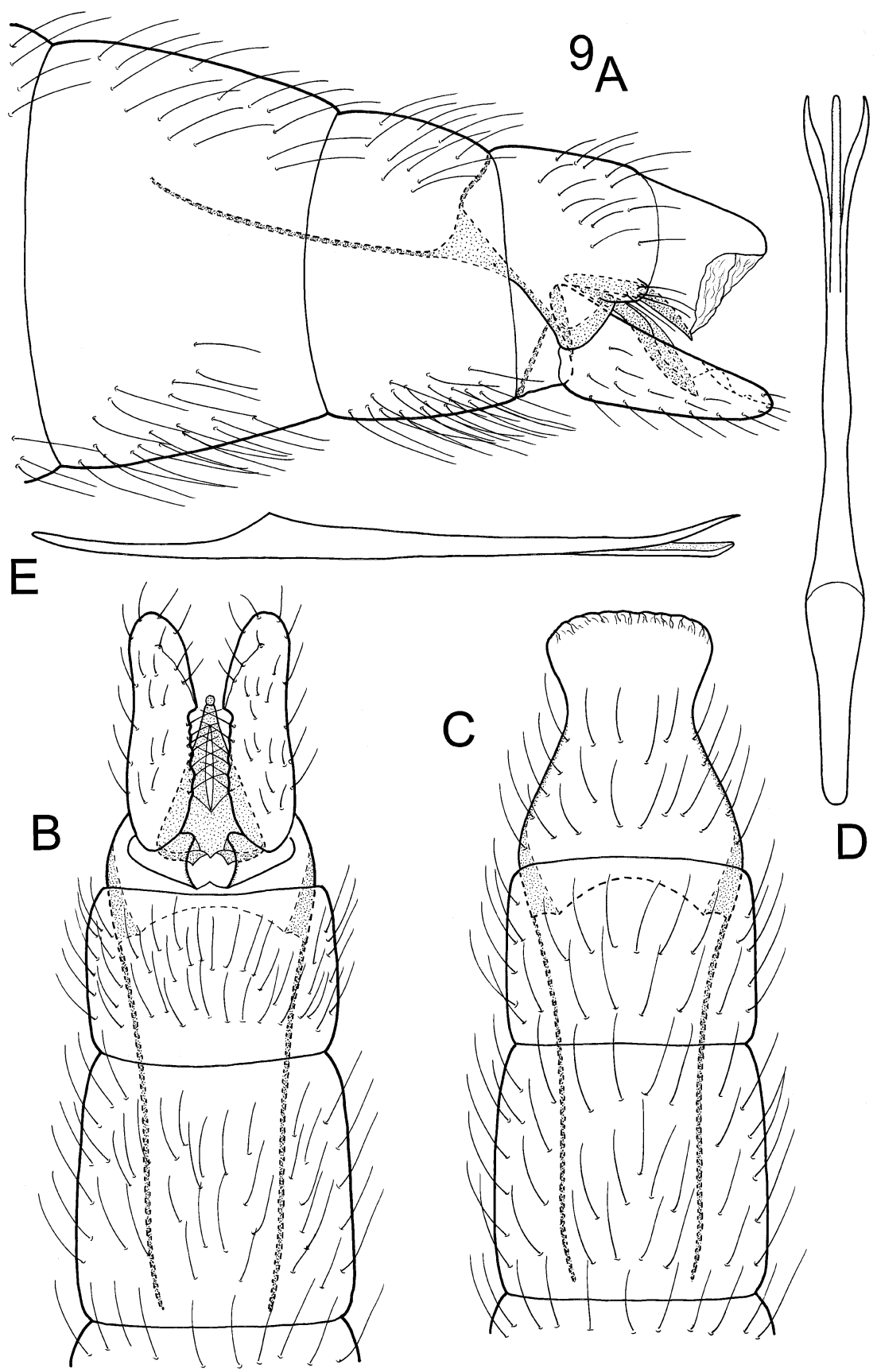

Fig. 9. Flintiella tamaulipasa new species, male genitalia. A. Lateral. B. Ventral. C. Dorsal. D. Phallus, dorsal. E. Phallus, lateral. 
Description. Male. Length 1.6-2.1 mm. Antenna with 18 segments. Brown in alcohol. Genitalia as in Fig. 9. Abdominal segments VII and VIII annular. Segment IX reduced ventrally; in dorsal view tapering posteriorly and fused with $\mathrm{X}$, anteriorly with lateral margins developed as thin, elongate rods which extend through segment VII; ventrally with U-shaped mesal cleft posteriorly. Segment X truncate in lateral view; dorsally narrow basally, widening distally to truncate apex. Inferior appendages triangular, gently tapering posteriorly; in ventral view rectangular, incised on mesal margins, rounded distally. Subgenital plate in lateral view thin and shelf-like, divided into three distal processes; in ventral view triangular, about $1 / 2$ length of inferior appendages, lateral processes nearly contiguous. Phallus tubular, deeply divided distally, ejaculatory duct protruding in the incision.

Female. Length 1.7-2.1 mm. Antenna with 17 segments. Coloration and overall appearance of head and thorax as in male. Genitalia as in Fig. 15. Abdominal segment VII annular. Segment VIII with rectangular ring of setae on posterior margin, pair of elongate mesal apodemes extending through segment VII, second pair of elongate apodemes originating at anterolateral margins and extending into segment VII. Segment IX short, tapering posteriorly to emarginate margin, pair of lateral apodemes connecting anteriorly with mesal apodemes of VIII. Segment X short and conical, bearing pair of papillae apically. Bursa copulatrix rounded posteriorly, narrowing to thin sclerite subapically, apex helmet-shaped, keyhole opening posteriorly, margins parallel-sided.

Types. Holotype, ơ: MEXICO, Tamaulipas, Rio Frio at La Poza Azul, near Gomez Farias, 18-V-1989, Harris \& Contreras (NMNH). Paratypes: MEXICO, Tamaulipas: same locality and data as holotype, 108 $\uparrow, 13$ \& (NMNH, UMSP, UNAM, CMNH). Chiapas: Cascada Misolja, $20 \mathrm{~km} \mathrm{S.} \mathrm{Palenque,} \mathrm{17-18-V-1981,} \mathrm{C.} \mathrm{\&} \mathrm{O.} \mathrm{Flint,} 1$ ๙ิ (NMNH). San Luis Potosi: Rio Salta, at hotel, along road to Salta del Agua, $46 \mathrm{~km}$ W Antigua Morelos, 15-V-1989, Harris \& Contreras, 1 to (UMSP).

Etymology. Named for the Mexican state of Tamaulipas.

Flintiella yanamona, new species

(Fig. 10)

Diagnosis. Flintiella yanamona is similar to the two preceding species in having a deeply incised phallic apex. It differs from $F$. tamaulipasa and is united with $F$. panamensis on the basis of the ventromesal process from segment VII. It is separated from both $F$. tamaulipasa and $F$. panamensis by the abruptly narrowing lateral lobes of the phallus apex and by the acute posterior narrowing of the inferior appendages. Flintiella yanamona is only known from a few localities in Peru.

Description. Male. Length 1.6-2.0 mm. Antenna with 18 segments. Brown in alcohol. Genitalia as in Fig. 10. Abdominal segment VII annular with short posteromesal process. Segment VIII annular. Segment IX reduced ventrally; in dorsal view gradually tapering posteriorly and fused with $\mathrm{X}$, anteriorly with lateral margins developed as thin, elongate rods which extend through segment VII; ventrally with deep, U-shaped mesal notch posteriorly. Segment X shelf-like in lateral view; dorsally narrow and rounded, mesal incision posteriorly. Inferior appendages boatshaped in lateral view, tapering posteroventrally to acute apex; in ventral view rectangular, rounded distally. Subgenital plate in lateral view thin and shelf-like, divided 

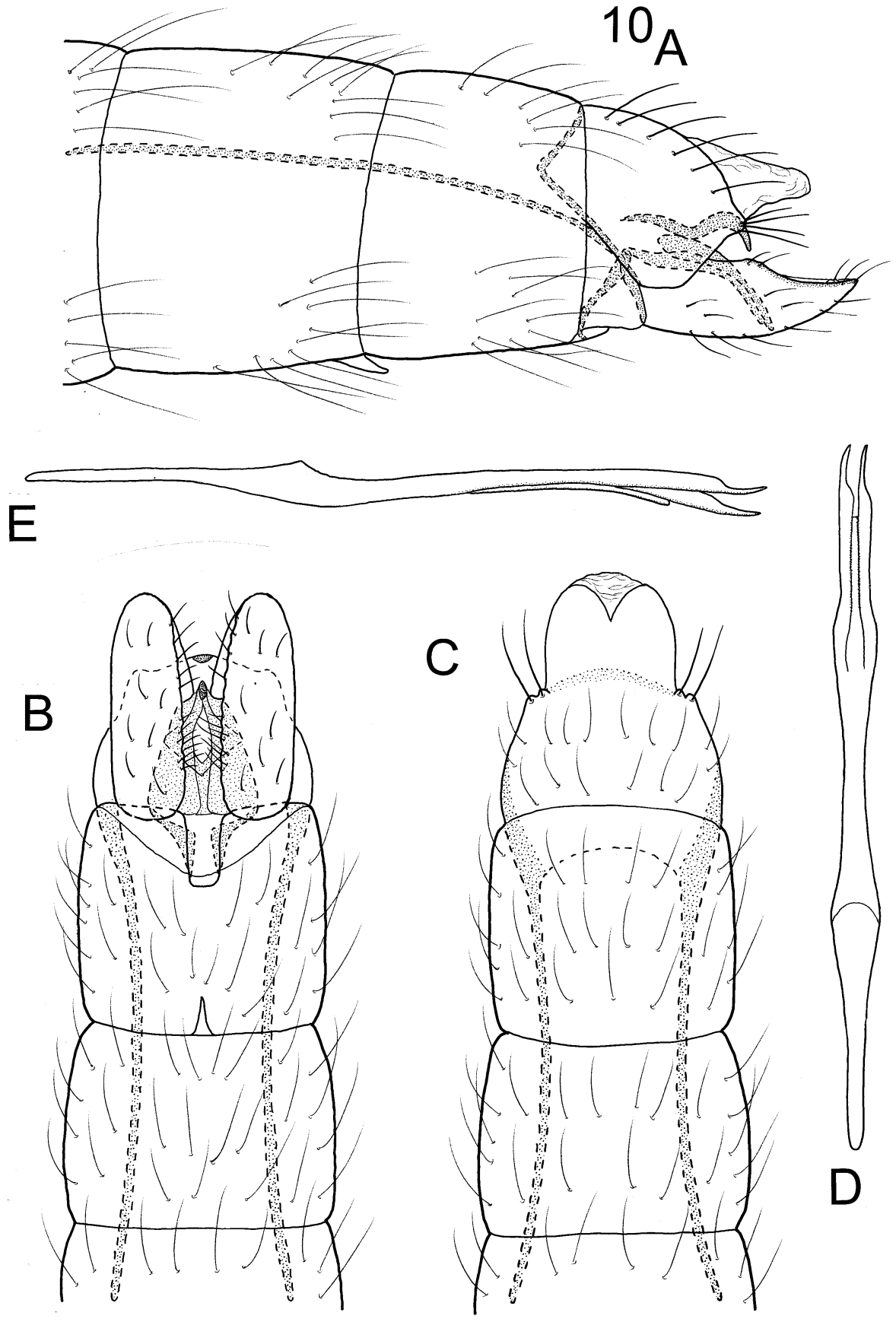

Fig. 10. Flintiella yanamona new species, male genitalia. A. Lateral. B. Ventral. C. Dorsal. D. Phallus, dorsal. E. Phallus, lateral. 

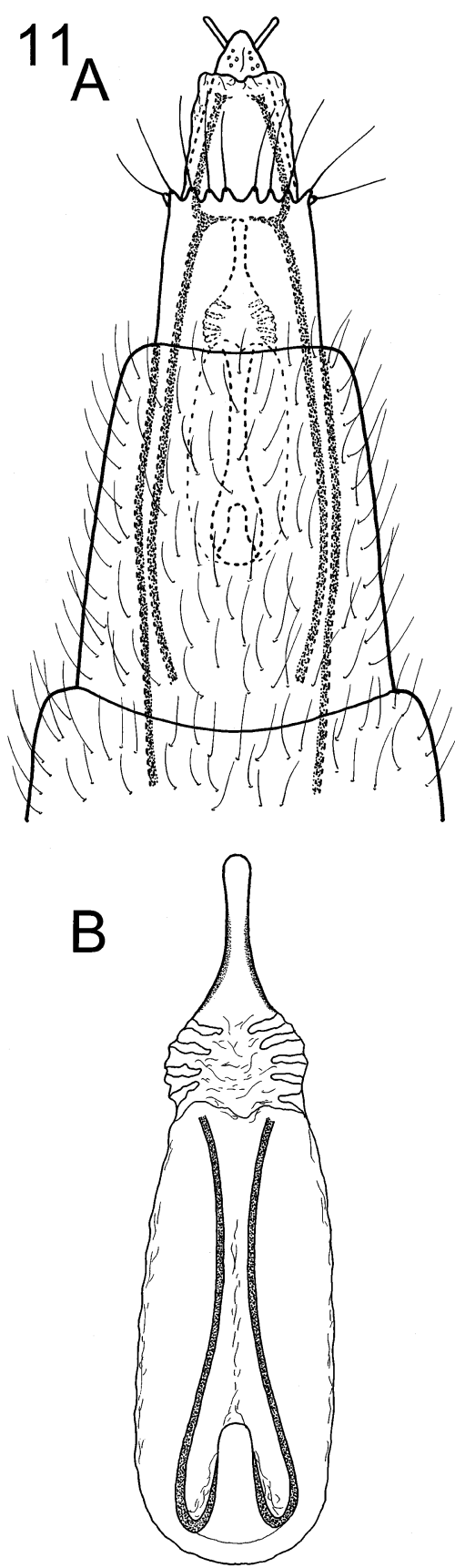

Fig. 11. Flintiella astilla new species, female genitalia. A. Terminal abdominal segments, ventral. B. Bursa copulatrix, ventral. 

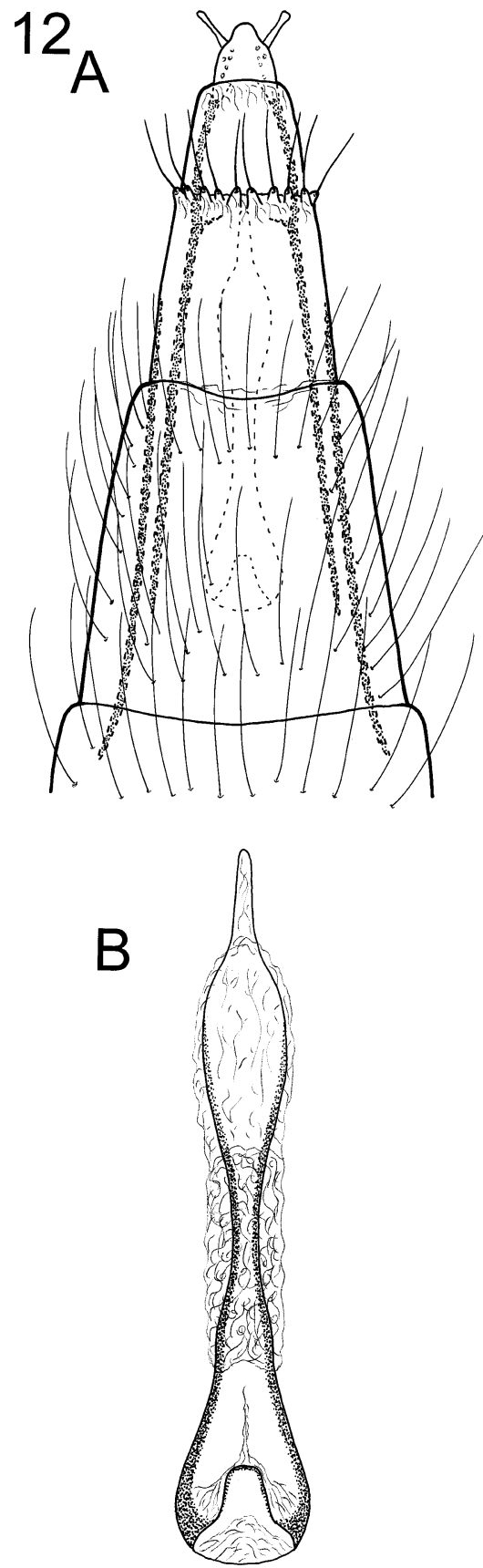

Fig. 12. Flintiella pizotensis new species, female genitalia. A. Terminal abdominal segments, ventral. B. Bursa copulatrix, ventral. 

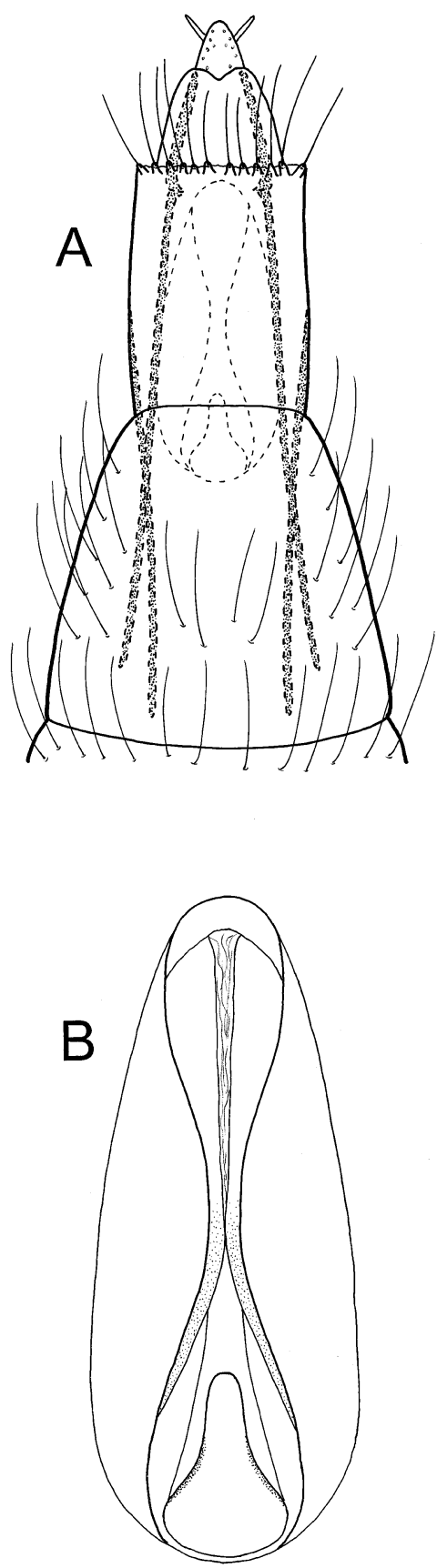

Fig. 13. Flintiella andreae Angrisano, female genitalia. A. Terminal abdominal segments, ventral. B. Bursa copulatrix, ventral. 

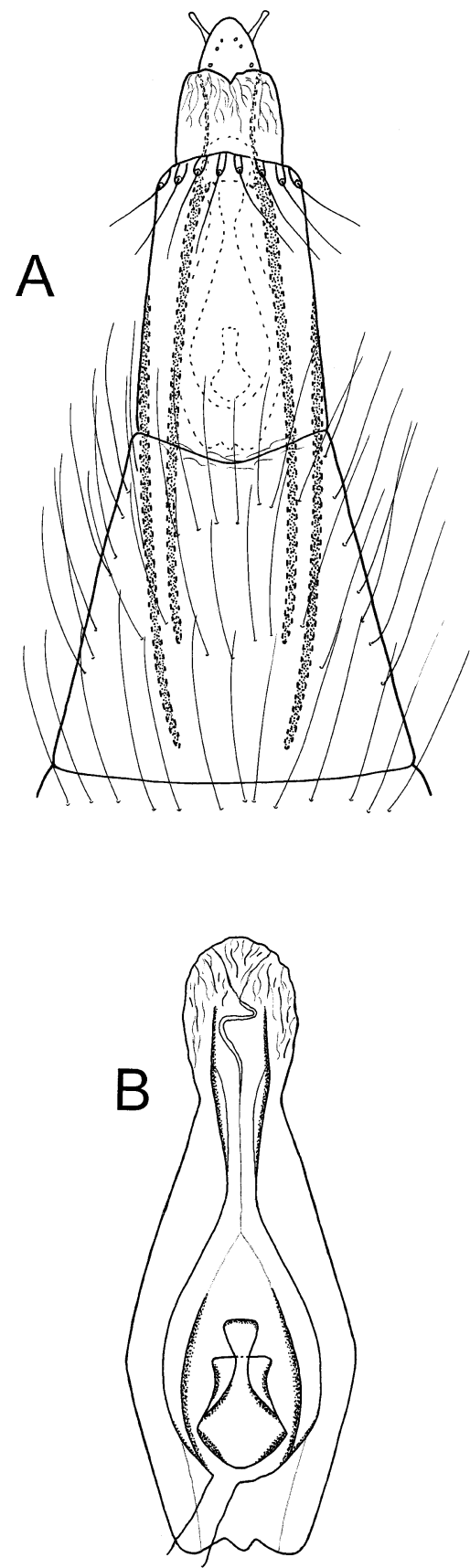

Fig. 14. Flintiella heredia new species, female genitalia. A. Terminal abdominal segments, ventral. B. Bursa copulatrix, ventral. 

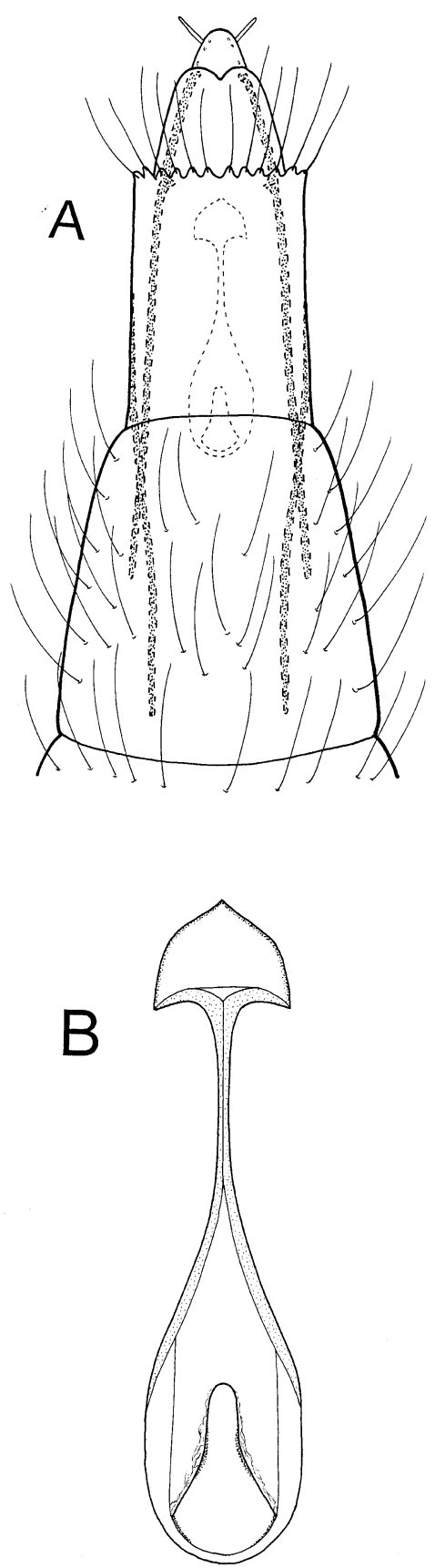

Fig. 15. Flintiella tamaulipasa new species, female genitalia. A. Terminal abdominal segments, ventral. B. Bursa copulatrix, ventral. 
into three distal processes, the ventral pair curving downward; in ventral view triangular, about half length of inferior appendages. Phallus tubular, deeply divided distally, the lateral lobes abruptly narrowing subapically.

Female. Unknown.

Types. Holotype, đ̊: PERU, Loreto, small stream near Explorama Lodge, 10-I-1997, L. Davenport (NMNH). Paratypes: PERU, Loreto: same locality and data as holotype, 10 o (NMNH, UMSP, CMNH); Yananomo Creek at Explorama Lodge, 30XII-1996, L. Davenport, 1 ô (UMSP). Madre de Dios: Manu, Pakitza, kitchen stream, malaise trap, night collection, $11^{\circ} 56^{\prime} \mathrm{S}, 71^{\circ} 18^{\prime} \mathrm{W}$, el. $250 \mathrm{~m}, 12-18-\mathrm{IX}-1988$, N. Adams et al., 1 के (NMNH); same locality but 1st stream, trail 2, malaise trap, day and night collection, $12^{\circ} 7^{\prime} \mathrm{S}, 70^{\circ} 58^{\prime} \mathrm{W}$, el. $250 \mathrm{~m}, 14-23-\mathrm{IX}-1988$, Flint \& Adams, 4 ơ (NMNH).

Etymology. Named for the Rio Yananomo, the major river in one of the localities where the species was collected.

\section{KEY TO FLINTIELLA SPECIES}

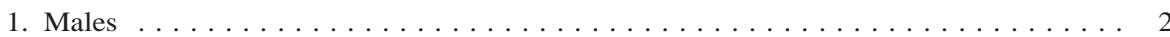

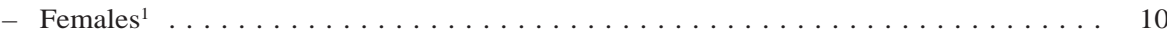

2. Inferior appendages fused, triangular in ventral view (Fig. 2B), in lateral view spinose dorsally, posteroventrally narrowing to thin, elongate process (Fig. 2A) . . . . . $\ldots \ldots \ldots \ldots \ldots \ldots \ldots \ldots \ldots \ldots$ Flintiella alajuela

- Inferior appendages not fused (Figs. 3C, 8B), in lateral view variously shaped, but

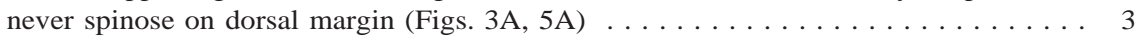

3. Dorsum of segment IX with sclerotized hooks or elongate spines (Figs. 3D, 4C) . . . 4

- Dorsum of segment IX without sclerotized hooks or spines (Figs. 5C, 7C) . . . . . . 5

4. Dorsum of segment IX with elongate spines (Fig. 3D); apodemes from anterior segment IX elongate, extending into segment VI (Fig. 3A); phallus widening apically and bear-

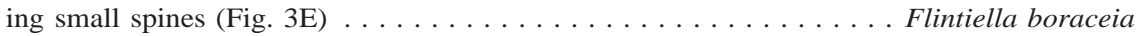

- Dorsum of segment IX with short hooks (Fig. 4C); apodemes from anterior segment IX short, not extending beyond segment VII (Fig. 4A); phallus narrow apically (Fig. $4 \mathrm{D}) \ldots \ldots \ldots \ldots \ldots \ldots \ldots \ldots \ldots \ldots \ldots \ldots \ldots$ Flintiella astilla

5. Phallus apex entire (Fig. 5D); inferior appendages in ventral view triangular, narrowing to acute apex (Fig. 5B); subgenital plate in ventral view narrowing at midlength, spinose apically $($ Fig. $5 \mathrm{~B}) \ldots \ldots \ldots \ldots$ Flintiella pizotensis

- Phallus apex divided (Figs. 7D, 8D); inferior appendages lobate in ventral view, rounded apically (Figs. 7B, 10B); subgenital plate triangular in ventral view (Figs. 6B, 9B)

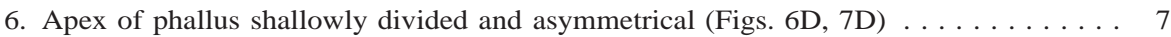

- Apex of phallus deeply divided and symmetrical (Figs. 8D, 10D) . . . . . . . . 8

7. Inferior appendages in lateral view narrowing abruptly posteroventrally and bearing distinct lobe on inner surface (Fig. 6A); posteroventral process on segment VII absent (Fig. 6B); subgenital plate short (Fig. 6A); apex of phallus twisted (Fig. 6D) . . . . .

$\ldots \ldots \ldots \ldots \ldots \ldots \ldots \ldots \ldots \ldots \ldots$ Flintiella andreae

- Inferior appendages in lateral view gradually narrowing posteroventrally, lacking distinct lobe on inner surface (Fig. 7A); posteroventral process present on segment VII (Fig. 7B); subgenital plate elongate (Fig. 7A); apex of phallus not twisted (Fig. 7D)

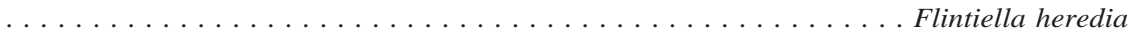

\footnotetext{
${ }^{1}$ Females of $F$. alajuela, $F$. boraceia, $F$. panamensis, and $F$. yanamona are unknown.
} 
8. Segment VII with ventromesal process; inferior appendages in lateral view abruptly narrowing posteroventrally $($ Figs. $8 \mathrm{~A}, 10 \mathrm{~A}) \ldots \ldots \ldots \ldots \ldots \ldots \ldots$

- Segment VII without a ventromesal process; inferior appendages in lateral view gradually narrowing posteroventrally (Fig. 9A) . . . . . . . F Flintiella tamaulipasa

9. Segment $X$ divided into a pair of lobes (Fig. 8C); inferior appendages narrowing distally in ventral view (Fig. 8B); phallus with apical lateral lobes gradually narrowing

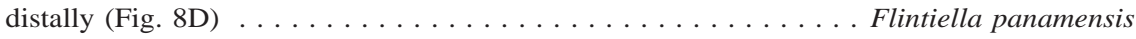

- Segment $\mathrm{X}$ entire (Fig. 10C); inferior appendages not narrowing distally in ventral view (Fig. 10B); phallus with apical lobes abruptly narrowing distally (Fig. 10D) . . .

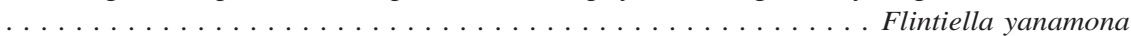

10. Posterior of bursa copulatrix narrowing to elongate, nipple-like process (Figs. 11B,

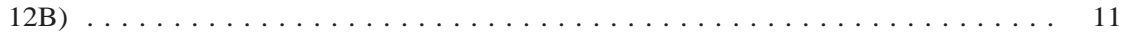

- Posterior of bursa copulatrix, broadly rounded, not elongate or nipple-like (Figs. 13B,

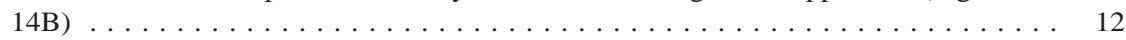

11. Keyhole and posterior structures surrounded by membranous sac, membranous region

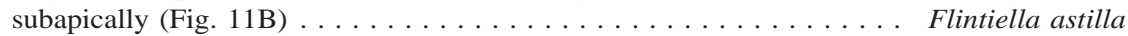

- Keyhole and posterior structures not surrounded by membranous sac, no membranous

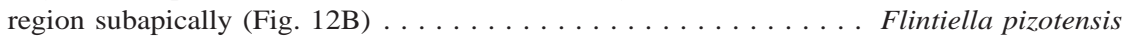

12. Keyhole and associated structures surrounded by membranous sac, mesal portion of keyhole sclerites not extremely narrowed (Figs. 13B, 14B) $\ldots \ldots \ldots \ldots \ldots \ldots$

- Keyhole and associated structures not surrounded by membranous sac, mesal portion of keyhole sclerites greatly narrowed, dome-like posteriorly (Fig. 15B) . . . . . $\ldots \ldots \ldots \ldots \ldots \ldots \ldots \ldots \ldots \ldots \ldots \ldots \ldots \ldots \ldots \ldots \ldots$

13. Posterior portion of bursa copulatrix about same width as anterior portion; keyhole structure of bursa copulatrix gradually narrowing posteriorly, sac surrounding bursa copulatrix oval (Fig. 13B) $\ldots \ldots \ldots \ldots \ldots$ Flintiella andreae

- Posterior portion of bursa copulatrix narrower than anterior portion; keyhole structure of bursa copulatrix narrowing mesally, sac surrounding keyhole structure narrowing subapically $($ Fig. 14B) . . . . . . . . . . . . . . . . Flintiella heredia

\section{ACKNOWLEDGMENTS}

Fieldwork in Costa Rica by Holzenthal was supported by National Science Foundation grant BSR-8512368. Subsequent systematics research by Holzenthal and Harris was supported by NSF grant DEB-9400632.

\section{LITERATURE CITED}

Angrisano, E. B. 1995. Contribuicion al conocimiento de los Trichoptera del Uruguay II. Familia Hydroptilidae. Revista Brasileira de Entomologia 39:501-516.

Flint, O. S. Jr., R. W. Holzenthal and S. C. Harris. 1999. Catalog of the Neotropical caddisflies (Insecta: Trichoptera). Ohio Biological Survey, Columbus, Ohio, 239 pp.

Harris, S. C., O. S. Flint, Jr., and R. W. Holzenthal. 2002a. Two new genera of Hydroptilidae from the Neotropics (Trichoptera: Hydroptilidae: Stactobiini). Journal of the New York Entomological Society, 110:49-64.

Harris, S. C., R. W. Holzenthal and O. S. Flint, Jr. 2002b. Review of the Neotropical genus Bredinia (Trichoptera: Hydroptilidae: Stactobiini). Annals of the Carnegie Museum, 71: 13-45.

Marshall, J. E. 1979. A review of the genera of the Hydroptilidae (Trichoptera). Bulletin of the British Museum of Natural history (Entomology) 39:135-239.

Received 25 August 2001; accepted 6 March 2002. 